Article

\title{
Parasitoid Complex of Fall Armyworm, Spodoptera frugiperda, in Ghana and Benin
}

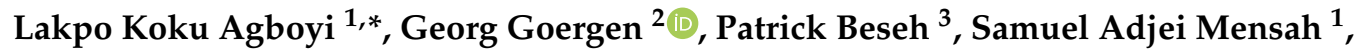 \\ Victor Attuquaye Clottey ${ }^{1}{ }^{\circledR}$, Raymond Glikpo ${ }^{3}$, Alan Buddie ${ }^{4}$, Giovanni Cafà ${ }^{4}{ }^{\circledR}$, Lisa Offord ${ }^{4}$, \\ Roger Day ${ }^{5}$ (D), Ivan Rwomushana ${ }^{5}\left(\mathbb{D}\right.$ and Marc Kenis ${ }^{6}$ \\ 1 CABI, P.O. Box CT 8630, Cantonments, Accra 0376800, Ghana; samuelmensah1a@gmail.com (S.A.M.); \\ v.clottey@cabi.org (V.A.C.) \\ 2 International Institute of Tropical Agriculture (IITA), 08 BP 0932 Tri Postal, Cotonou, Benin; \\ g.goergen@cgiar.org \\ 3 Plant Protection and Regulatory Services Directorate (PPRSD), P.O. Box M37, Accra 00495426, Ghana; \\ pkbeseh@gmail.com (P.B.); glikporaymond@yahoo.com (R.G.) \\ 4 CABI, Bakeham Lane, Egham TW20 9TY, UK; a.buddie@cabi.org (A.B.); g.cafa@cabi.org (G.C.); \\ 1.offord@cabi.org (L.O.) \\ 5 CABI, 673 Limuru Road, Muthaiga, P.O. Box 633, Nairobi 00621, Kenya; r.day@cabi.org (R.D.); \\ i.rwomushana@cabi.org (I.R.) \\ 6 CABI, 1 Rue des Grillons, 2800 Delémont, Switzerland; m.kenis@cabi.org \\ * Correspondence: 1.agboyi@cabi.org; Tel.: +233-246-723-292
}

Received: 11 December 2019; Accepted: 16 January 2020; Published: 21 January 2020

\begin{abstract}
The fall armyworm, Spodoptera frugiperda, a moth originating from the American continent, has recently invaded most African countries, where it is seriously threatening food security as a pest of cereals. The current management methods rely heavily on the use of synthetic insecticides but there is a need for more sustainable control methods, including biological control. Surveys were conducted in two West African countries, Ghana and Benin, to determine the native parasitoid complex and assess parasitism rates of $S$. frugiperda. Samples of $S$. frugiperda eggs and larvae were collected in maize fields located in 56 and 90 localities of Ghana and Benin, respectively, from July 2018 to July 2019. Ten species were found parasitizing the pest, including two egg parasitoids, one egg-larval, five larval and two larval-pupal parasitoids. The two most abundant parasitoids in both countries were two Braconidae: the egg-larval parasitoid Chelonus bifoveolatus and the larval parasitoid Coccygidum luteum. Parasitism rates were determined in three Ghanaian regions and averages varied from $0 \%$ to $75 \%$ between sites and from $5 \%$ to $38 \%$ between regions. These data provide an important baseline for the development of various biological control options. The two egg parasitoids, Telenomus remus and Trichogramma sp. can be used in augmentative biological control and investigations should be conducted to assess how cultural practices can enhance the action of the main parasitoids, C. luteum and Ch. bifoveolatus, in the field. Understanding the parasitoid complex of S. frugiperda in Africa is also necessary before any development of classical biological controls involving the introduction of parasitoids from the Americas.
\end{abstract}

Keywords: biological control; Chelonus bifoveolatus; Coccygidum luteum; Telenomus remus; Trichogramma; West Africa

\section{Introduction}

The fall armyworm, Spodoptera frugiperda (J.E. Smith) (Lepidoptera: Noctuidae), is a polyphagous pest originating from tropical and subtropical America, where it undergoes long-distance annual migrations [1]. Known mostly as a major pest of maize and other cereals [2], it has recently invaded 
most maize agroecosystems in Africa and it is now rapidly spreading in Asia [3-5]. In West Africa, S. frugiperda was first reported in Benin, Nigeria and Togo in 2016 [5,6] and one year later in Ghana [7]. The species does not diapause, and the favourable climatic conditions in most African countries allow the pest to complete several generations per year, wherever host plants are available, including off-season and irrigated crops [8]. Left unmanaged and in the absence of natural antagonists, S. frugiperda has been reported to cause significant yield losses in maize and other crops in Africa $[9,10]$.

In Africa, the immediate response for the management of this pest has focused primarily on synthetic insecticides, many of which are, as yet, unregistered for use on this new threat $[4,11]$. Although there is a deliberate effort in some countries to develop and promote integrated approaches for the control of $S$. frugiperda, many farmers still rely on chemical insecticides [4,12,13]. This practice is not only costly to the farmer and economically unsustainable for resource-poor farmers, but it poses a risk to human health, can cause environmental pollution, and can favour the development of insecticide resistance, as found in the Americas [14,15]. The frequent and improper use of pesticides could also disrupt the effectiveness of other integrated pest management measures targeted at other pests, such as stemborers, in maize cropping systems. The sustainable management of this invasive pest, therefore, requires the development and dissemination of ecologically friendly crop protection methods. Biopesticides could be an option, but a recent analysis of the availability of biopesticides in Africa revealed that in many countries few active ingredients are registered and most of them are not yet registered against $S$. frugiperda [16]. Methods such as the use of botanicals have recently been suggested as another suitable option $[10,16,17]$, but their wider use is constrained by availability and cost. Therefore, biological control approaches that exploit the use of parasitoids and predators become viable alternatives for the management of this pest, particularly among resource-constrained smallholder farmers.

Parasitoids and predators can be used against $S$. frugiperda through the augmentation or conservation of natural enemies that already occur in the target environment. However, there is presently limited available information on the natural enemies of S. frugiperda in Africa. Some authors studied the parasitoid complex of the pest in Ethiopia, Kenya, Tanzania [18,19] and Senegal [20]. In addition, the platygasterid egg parasitoid Telenomus remus Dixon was recorded in Côte d'Ivoire, Benin and Niger [21] and the biology of the braconid larval parasitoid (Coccygidium luteum Brullé) has recently been studied in Ghana [22]. There are many known natural enemies of S. frugiperda from North, Central and South America that play an important role in the natural suppression of this pest in its area of origin (e.g., [23-28]) and could potentially be considered for introduction into Africa. Parasitoids are probably better candidates for introduction since at least some of them may be rather specific, whereas all predators attacking S. frugiperda are known to be polyphagous [8]. However, the importation of American parasitoids into Africa also requires preliminary studies of the parasitoid complex of the moth in the invaded area, to assess potential gaps in the complex that could be filled with exotic species, as well as to assess possible competitive interaction between exotic and native parasitoids [29].

The present study was undertaken to provide an inventory of the parasitoid complex of S. frugiperda in two West African countries, Ghana and Benin, in order to evaluate their potential use as biological control agents.

\section{Materials and Methods}

\subsection{Surveys in Ghana}

In Ghana, samples were collected in 56 localities from nine regions, from the north to the south of the country. Supplementary Table S1 provides details of the collection sites with a description of the ecological zone. The collections were conducted during the maize growing seasons from July to November 2018, in maize fields that had not been previously treated with insecticides. The samples collected from the Eastern, Volta and Central regions were used to provide quantitative data on 
parasitism rates, whereas the samples from the other six regions were used to provide qualitative information on the presence of a given parasitoid on S. frugiperda in a specific region.

Different larval stages of $S$. frugiperda and egg masses were collected randomly and carried to the biological control laboratory of the Plant Protection and Regulatory Services Directorate of Ghana in Accra. The egg masses were collected with a piece of maize leaf on which they were found and placed in plastic vials with humid paper. Some larval samples were brought in bulk but, to avoid cannibalism, in the collections used for quantitative analyses, each larva was kept separately in an aerated plastic disposable cup $(80 \mathrm{~mL})$ containing a piece of tissue paper. Larvae and eggs were kept in the laboratory at an ambient temperature of $26-30{ }^{\circ} \mathrm{C}, 70 \%-90 \%$ relative humidity. Leaves collected from 3-4-week old untreated maize plants grown in a greenhouse were used to feed the larvae individually in their cups. The maize leaves were changed every two days until the emergence of a parasitoid adult or a S. frugiperda moth. Egg masses were kept individually until hatching or parasitoid emergence, in aerated plastic cups $(650 \mathrm{~mL})$ also containing a piece of dry tissue paper and untreated maize leaves. The data on the development of $S$. frugiperda and the emergence of parasitoids were collected every two days. All parasitoids species that emerged from the samples were conserved in $99 \%$ alcohol for morphological and molecular identifications.

In addition, a field collection of S. frugiperda egg masses was carried out on 30 July 2019 at three farms in Somanya, Eastern Province, where eggs were particularly abundant. The egg masses were collected and processed as described above.

\subsection{Surveys in Benin}

Rainfall in Benin follows a unimodal pattern in the northern part of the country (from June to September) and a bimodal pattern in the southern regions (from March to July and September to November). Thus, to meet the maize growing season across the whole country, it was decided to organize two separate field surveys. A first survey was conducted from end of July to the beginning of August 2018 for northern Benin and a second in mid-October 2018 for the southern regions stretching from Bohicon in the centre to Cotonou at the littoral. During each of the surveys, stops were made at $20 \mathrm{~km}$ intervals following a North-South transect to scout for egg masses and immatures of S. frugiperda using the standard procedure laid out in [8]. In total, 90 stops were made at different locations, enabling visits to 102 maize fields (Supplementary Table S1). Samples of detected egg masses and immatures were brought back to the IITA station-Benin for laboratory rearing according to the method described above.

In addition to these surveys, the egg parasitism of S. frugiperda was determined by collecting and rearing egg masses that were sampled every two days during the entire month of June 2019 on young maize plants in fields that had been prepared at the IITA station at Calavi. The collected egg batches were held in $8 \mathrm{~mL}$ plastic vials sealed with cotton wool and maintained at an ambient temperature for insect emergence. The vials were regularly monitored for 15 days. Representative specimens were used for barcoding and voucher samples of adult insects from all recovered species were deposited in the reference collection of the Biodiversity Centre at the IITA station, Benin.

\subsection{Morphological and Molecular Identification}

All parasitoids obtained during these studies were examined and morphologically identified using various identification keys and taxonomic descriptions (e.g., [30-33]) by two authors (GG and MK) and collections at CABI and IITA-Benin for specimen comparisons. Some representative specimens were brought to the Natural History Museum London for comparison with the collection holdings and were identified with the assistance of group specialists. In addition, samples of each species were subjected to molecular analyses using the mtDNA barcode gene in order to compare them with existing barcode datasets. To obtain barcodes (around $600 \mathrm{bp}$ of the mitochondrial gene (mtDNA) cytochrome c oxidase subunit 1 (COI)) from the samples, we followed the protocols described in [21]. The sequences obtained in the present study were compared with authenticated sequences available 
from the Barcoding of Life Data system (BOLD; http://www.boldsystems.org/) [34] and additional sequences from the GenBank ${ }^{\circledR}$ data base (http://www.ncbi.nlm.nih.gov/genbank/) [35].

\subsection{Relative Abundance and Parasitism Rates}

The relative abundance of larval parasitoids and larval parasitism rates were assessed at sites in the Eastern, Volta and Central regions in Ghana, where S. frugiperda larvae were sampled regularly (sites indicated by * in Supplementary Table S1). For the other collections, mortality by cannibalism and other intrinsic and extrinsic causes during transfer to the laboratory was too high to provide reliable data on parasitism.

The relative abundance of a parasitoid species (RA) was determined by calculating the number of individuals of each parasitoid species $\left(N_{i}\right)$ in the total number of parasitoids obtained from the sample collected $\left(N_{t}\right)$ and expressing this value as a percentage.

The parasitism rate (PR) was calculated as the number of a parasitoid species (or all parasitoids species for the case of total parasitism) divided by the total number of parasitoids and hosts that reached at least the pupal stage from the sample collected, expressed as a percentage. The hosts that died at the larval stage were not included in the calculation, since it could not be determined whether they were parasitized or not. No gregarious parasitoids were observed in the samples.

Parasitism rates were also estimated from samples of egg masses collected in July 2019 in Somanya in Ghana and in June 2019 at the IITA station in Calavi. The percentage of egg masses providing egg parasitoids was calculated and, in Benin, the percentage of parasitized eggs per egg mass was measured.

\section{Results}

\subsection{Parasitoid Complex of S. frugiperda in Ghana and Benin}

Ten parasitoid species were found in the two countries—eight in Ghana and nine in Benin-from which DNA barcode sequences were obtained (Table 1).

Table 1. Parasitoid species emerged from S. frugiperda eggs and larvae collected in maize farms in Ghana $(\mathrm{GH})$ and Benin (BE).

\begin{tabular}{|c|c|c|c|}
\hline Order, Family and Species & Country & $\begin{array}{c}\text { Host Stage } \\
\text { Attacked/Killed }\end{array}$ & $\begin{array}{l}\text { Barcoding Results: GenBank Accession } \\
\text { Number; Closest Species or Genus }\end{array}$ \\
\hline \multicolumn{4}{|l|}{ Hymenoptera: Platygastridae } \\
\hline Telenomus remus Dixon & $\mathrm{GH}, \mathrm{BE}$ & Egg & $\begin{array}{l}\text { MN900731, MN900732; } 100 \% \text { similar to T. remus } \\
\text { in [21] }\end{array}$ \\
\hline \multicolumn{4}{|l|}{ Hymenoptera: Trichogrammatidae } \\
\hline Trichogramma sp. & $\mathrm{BE}$ & Egg & $\begin{array}{l}\text { MN900733; } 98.9 \% \text { similar to a Trichogramma sp. } \\
\text { on Helicoverpa armigera (Hübner) in Mali } \\
\text { (unpublished data) }\end{array}$ \\
\hline \multicolumn{4}{|l|}{ Hymenoptera: Braconidae } \\
\hline Chelonus bifoveolatus Szépligeti & $\mathrm{GH}, \mathrm{BE}$ & Egg-larval & $\begin{array}{l}\text { MN900730, MN900734, MN900743, MN900744; } \\
>99 \% \text { similar to Chelonus sp. from Africa, Asia } \\
\text { and Polynesia }\end{array}$ \\
\hline Coccygidium luteum (Brullé) & $\mathrm{GH}, \mathrm{BE}$ & Larval & $\begin{array}{l}\text { MN900728, MN900739, MN900741; 99\% similar } \\
\text { to Coccygidium sp from Bangladesh }\end{array}$ \\
\hline $\begin{array}{l}\text { Cotesia icipe Fernandez-Triana and } \\
\text { Fiaboe }\end{array}$ & $\mathrm{GH}, \mathrm{BE}$ & Larval & MN900735; 100\% similar to type specimen [33] \\
\hline Meteoridea cf. testacea (Granger) & $\mathrm{GH}, \mathrm{BE}$ & Larval-pupal & $\begin{array}{l}\text { MN900738; } 89.7 \% \text { similar to Meteoridea sp. from } \\
\text { Papua New Guinea }\end{array}$ \\
\hline \multicolumn{4}{|l|}{ Hymenoptera: Ichneumonidae } \\
\hline Charops sp. & $\mathrm{GH}, \mathrm{BE}$ & Larval & $\begin{array}{l}\text { MN900729; MN900742; } 89.6 \% \text { similar to Charops } \\
\text { cantator }\end{array}$ \\
\hline Metopius discolor Tosquinet & $\mathrm{GH}$ & Larval-pupal & $\begin{array}{l}\text { MN900737, MN900740; } 96.3 \% \text { similar to Metopius } \\
\text { sp. from South Africa }\end{array}$ \\
\hline Pristomerus pallidus (Kriechbaumer) & $\mathrm{BE}$ & Larval & $\begin{array}{l}\text { MN900727; } 99.5 \% \text { similar to Pristomerus pallidus } \\
\text { from Senegal [36] }\end{array}$ \\
\hline \multicolumn{4}{|l|}{ Dipt: Tachinidae } \\
\hline Drino quadrizonula (Thomson) & $\mathrm{GH}, \mathrm{BE}$ & Larval & $\begin{array}{l}\text { MN907776; } 99.8 \% \text { similar to Drino sp. } \\
\text { from Kenya }\end{array}$ \\
\hline
\end{tabular}


They included two egg parasitoid species, one egg-larval parasitoid species, five larval parasitoid species, and two larva-pupal parasitoid species. Chelonus bifoveolatus Szépligeti and C. luteum were the most abundant and frequent species encountered, being present in nine and seven regions, respectively, out of the nine surveyed Ghanaian regions, and eight departments of the 10 visited departments in Benin, respectively (Tables 2 and 3). They were collected in 23 and 16 localities, respectively, from a total of 56 localities visited in Ghana. The remaining larval parasitoid species were less frequently collected. The egg parasitoid T. remus was found only at three and 24 locations in Ghana and Benin, respectively. However, in Ghana, S. frugiperda egg masses were collected only in a part of the investigated localities and were specifically searched only at one locality (Somanya, Eastern Region).

Table 2. Parasitoids of Spodoptera frugiperda in different localities of Ghana in 2018.

\begin{tabular}{|c|c|c|c|c|c|c|c|c|c|}
\hline \multirow{3}{*}{ Region } & \multirow{3}{*}{ Locality } & \multicolumn{8}{|c|}{ Natural Enemies of $S$. frugiperda } \\
\hline & & \multirow{2}{*}{$\begin{array}{c}\begin{array}{c}\text { Egg } \\
\text { Parasitoid }\end{array} \\
\text { Tel. }\end{array}$} & \multirow{2}{*}{$\begin{array}{c}\text { Egg-Larval } \\
\text { Parasitoid } \\
\text { Chel. }\end{array}$} & \multicolumn{4}{|c|}{ Larval Parasitoid } & \multicolumn{2}{|c|}{$\begin{array}{c}\text { Larval-Pupal } \\
\text { Parasitoid }\end{array}$} \\
\hline & & & & Coc. & Cot. & Cha. & Dri. & Metop. & Meteo. \\
\hline \multirow{6}{*}{ GH-Eastern } & Somanya * & + & + & + & + & + & & & \\
\hline & Okwenya * & & + & & & & & + & \\
\hline & Kpong & + & & & & & & & \\
\hline & Apese * & & & + & & & & & \\
\hline & Apewu & & & + & & & & & \\
\hline & Adawso & & + & & & & + & & \\
\hline \multirow{7}{*}{ GH-Volta } & Togome* & & + & + & & & & & \\
\hline & Anyirawase * & & + & + & & + & & & \\
\hline & Agbokope * & & + & + & & & & & \\
\hline & Tsito * & & & & & + & & & \\
\hline & Dabala * & & & + & & + & & & \\
\hline & Matse & & + & & + & & & & \\
\hline & Adaklu & & + & & + & & & & \\
\hline \multirow{5}{*}{$\begin{array}{c}\text { GH-Central } \\
\text { Accra }\end{array}$} & Jukwa * & & & & & + & & & \\
\hline & Cape Coast campus * & & & + & & + & & & \\
\hline & Assin-Endwa & & & & & + & & & \\
\hline & Yamoransa & & & + & & & & & \\
\hline & Ekumfi-Edukuma & & + & + & & + & & & \\
\hline GH-Greater-Accra & Adenta & + & + & + & & & & & + \\
\hline \multirow{4}{*}{ GH-Ashanti } & Akyeremade & & & + & & & & & \\
\hline & Adidwan & & & + & & & + & & \\
\hline & Ejura farms & & & + & + & + & + & + & \\
\hline & Breku & & & + & & & & & \\
\hline \multirow{4}{*}{$\begin{array}{l}\text { GH-Brong } \\
\text { Ahafo Region }\end{array}$} & Madina (Busunya road) & & + & & & & & & \\
\hline & Dobidi Nkwanta & & + & + & & + & + & - & - \\
\hline & Prang & & & + & & & & & \\
\hline & Dawadawa & & & + & & & & & \\
\hline \multirow{5}{*}{ GH-Northern } & Wasipe & & & + & & & & & \\
\hline & Sanyeri & & + & + & & & & & \\
\hline & Kukobila & & + & & & & & & \\
\hline & Zangbalum & & + & & & & & & \\
\hline & Benyunkwa & & & + & & & & & \\
\hline $\begin{array}{c}\text { GH-Upper } \\
\text { West }\end{array}$ & Sakalu & & & + & & & & & \\
\hline $\begin{array}{l}\text { GH-Upper } \\
\text { East }\end{array}$ & Wiaga & & + & + & & & + & & \\
\hline
\end{tabular}


Table 3. Parasitoids of Spodoptera frugiperda in different localities of Benin in 2018.

\begin{tabular}{|c|c|c|c|c|c|c|c|c|c|}
\hline \multirow[b]{2}{*}{ Region } & \multirow[b]{2}{*}{ Locality } & \multicolumn{8}{|c|}{ Natural Enemies of $S$. frugiperda } \\
\hline & & $\begin{array}{c}\begin{array}{c}\text { Egg } \\
\text { Parasitoid }\end{array} \\
\text { Tel. }\end{array}$ & $\begin{array}{c}\begin{array}{c}\text { Egg-Larval } \\
\text { Parasitoid }\end{array} \\
\text { Chel. }\end{array}$ & \multicolumn{4}{|c|}{ Larval Parasitoid } & \multicolumn{2}{|c|}{$\begin{array}{l}\text { Larval-Pupal } \\
\text { Parasitoid }\end{array}$} \\
\hline \multirow[t]{2}{*}{ Atacora } & Natitingou range & & & + & & & & & \\
\hline & Toukountouna & & & + & & & & & \\
\hline \multirow{6}{*}{ Atlantique } & Cococodji & + & + & & & & & & \\
\hline & Massi & + & & & & & & & \\
\hline & Ouidah & & + & + & & & & & \\
\hline & Sékou & & + & & & + & & & \\
\hline & Sérouhé & + & & + & & + & & & \\
\hline & Womey & + & & & & & & & + \\
\hline Borgou & Parakou range & + & & & & & & & \\
\hline \multirow[t]{4}{*}{ Collines } & Bante & & + & + & & & & & \\
\hline & Dassa & & & & & + & & & \\
\hline & Gobe & + & & & & & & & \\
\hline & Savalou & & + & & & & & & \\
\hline \multirow[t]{2}{*}{ Couffo } & Aplahoué & + & & & & & & & \\
\hline & Hagoumey & + & + & & & & & & \\
\hline \multirow[t]{3}{*}{ Donga } & Aoro & & + & + & & & & & \\
\hline & Basilla & + & & & & & & & \\
\hline & Prékété & + & & + & & & & & \\
\hline Ouémé & Sémé-Kpodji & + & + & & & & & & \\
\hline \multirow[t]{4}{*}{ Zou } & Bohicon & + & + & + & & + & + & & \\
\hline & Kpédékpo & + & & & & & & & \\
\hline & Passagon & & + & + & & & + & & \\
\hline & Setto & + & & & & & & & \\
\hline
\end{tabular}

Tel.: Telenomus remus; Che.: Chelonus bifoveolatus; Coc.: Coccygidium luteum; Cot.: Cotesia icipe; Cha.: Charops sp.; Dri.: Drino quadrizonula; Metop.: Metopius discolour; Meteo.: Meteoridea cf. testacea; + Parasitoid species present in the locality; only localities where parasitoids were found are listed in this table.

In Ghana, in the East and Ashanti regions, the number of parasitoid species recorded was seven and five, respectively. In the Volta and Brong Ahafo regions, four parasitoid species were collected. In the five other regions, the number of parasitoid species collected ranged between one and three, with only one species being found in the Upper West region (Table 2).

\subsection{Relative Abundance of S. frugiperda Parasitoids and Parasitism Rates}

Quantitative data on S. frugiperda larval parasitoids assessed in selected localities of the Eastern, Volta and Central regions of Ghana are presented in Tables 4 and 5. Coccygidium luteum and Ch. bifoveolatus were by far the most abundant parasitoid species, with a relative abundance estimated at $49 \%$ and $48 \%$ in the Eastern Region and $44 \%$ and $41 \%$ in the Volta Region, respectively (Table 4 ). In contrast, in the Central region, $\mathrm{Ch}$. bifoveolatus was not present in the quantitative samples and C. luteum was the most abundant (69\%), followed by Charops sp. (31\%). All other larval or larval-pupal parasitoids were rare $(\mathrm{RA}<1 \%)$ or absent in the three regions. 
The highest total larval parasitism rate was observed in the Eastern region (38.8\%), followed by the Volta region (10.7\%) and the Central region (5.1\%) (Table 4). At the species level, C. luteum and Ch. bifoveolatus caused an average of $19.3 \%$ and $18.9 \%$ parasitism, respectively, in the Eastern region. Parasitism was much lower in the Volta and Central regions (Table 4). With respect to the specific locations, the parasitism rate reached $75.0 \%$ in Somanya (Eastern region) in August 2018, with C. luteum and Ch. bifoveolatus being the main parasitoids (Table 5). Overall, the larval parasitism rates decreased from August to November 2018.

In Ghana, 174 egg masses were recovered from farm surveys carried out at three sites in the Eastern Region in July 2019, and 45 of them (25.9\%) were parasitized by T. remus. In Benin, a total of 145 egg masses were recovered in maize fields following 33 days of sampling. Egg parasitism was observed in $14.5 \%$ of the reared egg batches, from which emerged an average of 42.1 parasitoids-i.e., a parasitism rate of $41.9 \%$ within attacked egg masses. Except for two occasions, where Trichogramma sp. and T. remus hatched together from the same egg mass, field parasitism in Benin led solely to the emergence of $T$. remus. 
Table 4. Abundance and parasitism rates by egg-larval and larval parasitoids of Spodoptera frugiperda in the Eastern, Volta and Central regions of Ghana. Mortality rates of the collected S. frugiperda larvae that died but produced no parasitoids are $9.3 \%, 7.0 \%$ and $1.6 \%$ in the Eastern, Volta and Central regions, respectively.

\begin{tabular}{|c|c|c|c|c|c|c|c|c|c|}
\hline \multirow{3}{*}{ Parasitoid Species } & \multicolumn{9}{|c|}{ Ghana Regions } \\
\hline & \multicolumn{3}{|c|}{$\begin{array}{l}\text { Eastern Region } \\
\quad(N=450)\end{array}$} & \multicolumn{3}{|c|}{$\begin{array}{l}\text { Volta Region } \\
\quad(N=890)\end{array}$} & \multicolumn{3}{|c|}{$\begin{array}{l}\text { Central Region } \\
\quad(N=255)\end{array}$} \\
\hline & $\begin{array}{c}\text { No. of } \\
\text { Individuals }\end{array}$ & $\begin{array}{c}\text { Relative } \\
\text { Abundance } \\
(\%)\end{array}$ & $\begin{array}{c}\text { Parasitism } \\
\text { Rate } \\
(\%)\end{array}$ & $\begin{array}{c}\text { No. of } \\
\text { Individuals }\end{array}$ & $\begin{array}{c}\text { Relative } \\
\text { Abundance } \\
(\%)\end{array}$ & $\begin{array}{c}\text { Parasitism } \\
\text { Rate } \\
(\%)\end{array}$ & $\begin{array}{c}\text { No. of } \\
\text { Individuals }\end{array}$ & $\begin{array}{c}\text { Relative } \\
\text { Abundance } \\
(\%)\end{array}$ & $\begin{array}{l}\text { Parasitism } \\
\text { Rate } \\
(\%)\end{array}$ \\
\hline Chelonus bifoveolatus & 85 & 48 & 18.9 & 41 & 43 & 4.6 & - & & \\
\hline Cotesia icipe & 2 & 1 & 0.4 & - & & & - & & \\
\hline Charops sp. & 1 & 1 & 0.2 & 10 & 11 & 1.1 & 4 & 31 & 1.6 \\
\hline Coccygidium luteum & 87 & 49 & 19.3 & 44 & 46 & 4.9 & 9 & 69 & 3.5 \\
\hline Total & 175 & & 38.8 & 95 & & 10.7 & 13 & & 5.1 \\
\hline
\end{tabular}

$N$ : Total Number of S. frugiperda larvae collected in maize farms in the region; - Absence of data due to absence of parasitoid species in samples used. 
Table 5. Percentage of parasitism by egg-larval and larval parasitoids of Spodoptera frugiperda in selected localities in Ghana from August to November 2018. The mortality rate of the collected S. frugiperda larvae that died without producing a parasitoid ranged between $2.3 \%$ and $17.6 \%, 5.3 \%$ and $13.6 \%$ and $0 \%$ and $9.3 \%$ in August, October and November 2018, respectively.

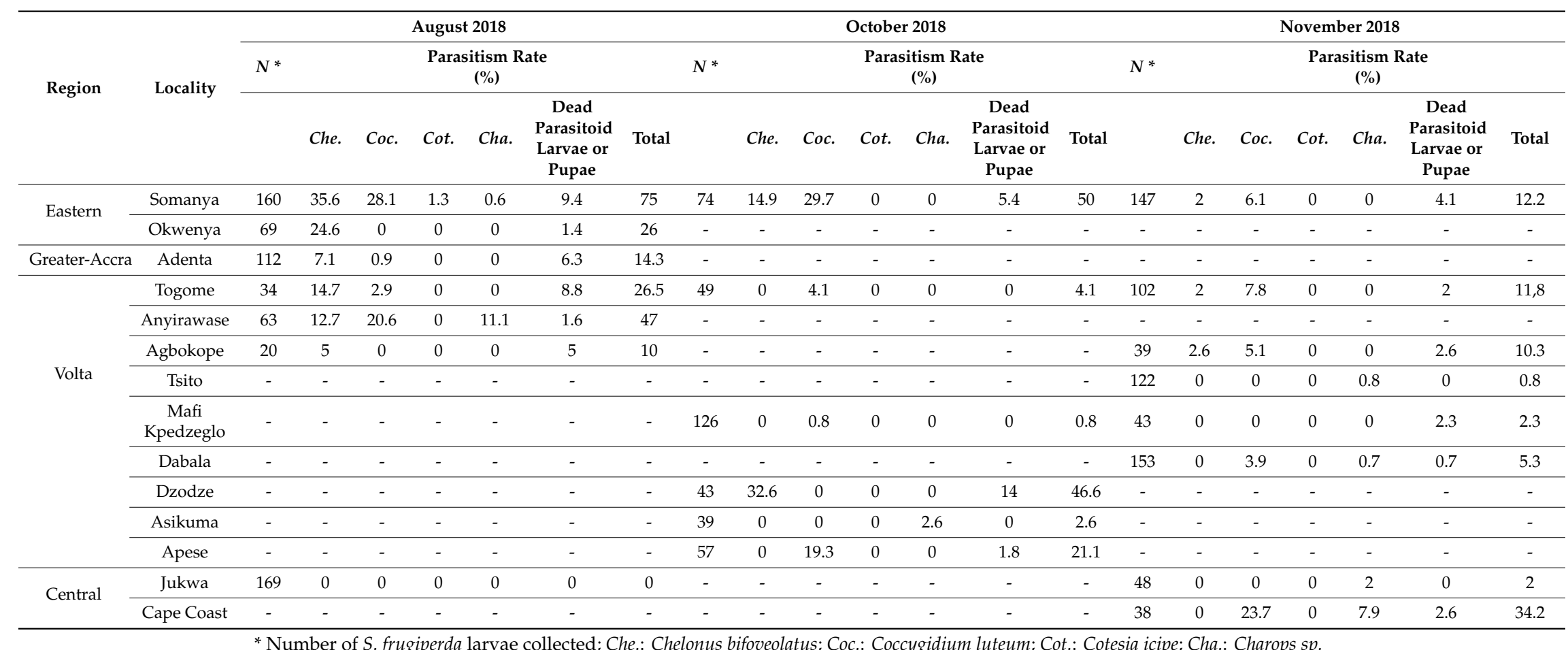

* Number of S. frugiperda larvae collected; Che.: Chelonus bifoveolatus; Coc.: Coccygidium luteum; Cot.: Cotesia icipe; Cha.: Charops sp. 


\section{Discussion}

\subsection{Parasitoid Complex and Parasitism of S. frugiperda in Ghana and Benin}

Ten parasitoid species attacking the eggs and larvae of S. frugiperda were found in Ghana and Benin. In similar surveys carried out in Ethiopia, Kenya and Tanzania, seven parasitoid species were collected [18,19]. The two main parasitoids of S. frugiperda in Ghana and Benin are two braconids, the larval parasitoid C. luteum and the egg-larval parasitoid Ch. bifoveolatus. Based on photos provided in [20], these were likely also the two larval parasitoids recovered from S. frugiperda in Senegal, even though the authors identified them as Campoletis sp. and Chelonus sp., respectively. Coccygidium luteum was also found to attack fall armyworms in Ethiopia, Kenya and Tanzania [18,19]. In contrast, two different Chelonus species were found in West and East Africa. Chelonus curvimaculatus Cameron was obtained in Kenya [18,19] whereas Ch. bifoveolatus, a comparatively larger species, is prevalent in Ghana and Benin. Moreover, numerous previous records of this parasitoid are reported from Burkina Faso, Cameroon, Chad, DR Congo, Madagascar, Nigeria, Sudan, Togo and Tanzania from Spodoptera spp. $[30,37,38]$. In Benin, Ch. bifoveolatus has occasionally been recovered from caterpillars of Spodoptera exigua (Hübner) feeding on onions in peri-urban vegetable gardens along the coast [39]. Interestingly, the barcode data indicate a $>99 \%$ congruence with the Chelonus species from Zimbabwe and Kenya but also from South Asia and Polynesia. The microgasterid Cotesia icipe was recorded in very low numbers in Ghana and Benin. By contrast, in Ethiopia, Kenya and Tanzania, it has become the most abundant larval parasitoid of $S$. frugiperda $[18,19]$ following its recent description from specimens obtained from S. exigua and Spodoptera littoralis (Boisduval) [33]. Since these two latter moth species are widely spread throughout sub-Saharan Africa (SSA), the reason for the sporadic occurrence of C. icipe on S. frugiperda in West Africa calls for further research.

The species of Charops reared from S. frugiperda in West Africa [this study] and East Africa [18,19] is possibly the same. However, the taxon cited in [18,19], Charops ater Szépligeti, is confusing [40]. Comparisons with the descriptions and type specimens of C. ater and other available African Charops species suggest that the species obtained from $S$. frugiperda in this study is likely undescribed. Until it is formally described, the taxon can be characterized by its barcode (Genbank accession numbers: MN900729; MN900742).

The tachinid D. quadrizonula collected in low numbers during our surveys in Ghana and Benin is closely related to the species Palexorista zonata (Curran) (= Drino imberbis [41]) found on S. frugiperda in Ethiopia and Kenya by [18,19], because Palexorista is a subgenus of Drino, according to the most recent classification of the Tachinidae of the Afrotropical region [42]. Drino quadrizonula is a widespread species in sub-Saharan Africa, and is known to parasitize a variety of moth larval hosts belonging to several families, though most records originate from Noctuidae, including several other Spodoptera spp. [43].

Three other native parasitoid species have adopted fall armyworm larvae as a new host and are here reported for the first time for Africa. Among these, four specimens of Pristomerus pallidus were collected in coastal Benin. Our molecular analyses showed that it is the same species as the one attacking the millet head miner, Heliocheilus albipunctella De Joannis, in Senegal [36]. Two larval-pupal parasitoids, Metopius discolor and Meteoridea cf. testacea, were reared in very low numbers. Metopius discolor is widespread in tropical Africa and commonly recorded from Spodoptera exempta (Walker), the African armyworm, which also attacks cereals [30,32]. Meteoridea is a rare genus, with only two known African species. The identification of the Meteoridea species is tentative and needs confirmation. The literature records indicate that a species of Meteoridea has already been reared from S. exempta in Tanzania [44] but the genus appears to be polyphagous as it can also develop in the pupae of the crambid Haritalodes derogata (Fabricius) in Africa [45].

Finally, two parasitoids were collected from eggs of $S$. frugiperda during our surveys. Telenomus remus is common and was recently found in other African countries [19,21]. Only three egg masses were found attacked by Trichogramma sp. in Benin and the specimens could not be identified to the species level. Trichogramma chelonis Ishii was recently reared from S. frugiperda in Kenya [19]; however, 
the barcode of the Benin specimens did not correspond to T. chelonis but to a Trichogramma sp. collected in Mali from egg batches of the noctuid moth Helicoverpa armigera (Barcode Index Number Registry For BOLD: ADS7997).

The field parasitism rates were very variable but sometimes surprisingly high for a newly invasive species. Larval parasitism of up to $75 \%$ was observed at one site. However, many collections did not result in any parasitoids. The new associations of native parasitoids with $S$. frugiperda might be attributable to the occurrence of several other Spodoptera species in West Africa, such as S. exempta, S. exigua and S. littoralis. Interestingly, there is only very little overlap between the parasitoid guild of S. frugiperda and the one associated with cereal stem borers such as Eldana saccharina Walker, Sesamia spp., Busseola fusca (Fuller), and Chilo aleniellus (Strand) [46-51].

In Ghana, larval parasitism was higher, and the parasitoid complex was richer, in the south than in the north. For example, Charops sp. was common in the south but not collected in the north. This could be due to ecological factors such as vegetation and rain patterns. In the south, the long periods of rains and higher plant and insect richness may offer better conditions for parasitoid diversity and proliferation.

Egg parasitism by T. remus was low, with $25.9 \%$ of the egg masses parasitized at one location in Ghana and 14.5\% at another location in Benin. In Kenya and Tanzania, authors [19] mention egg parasitism rates by $T$. remus above $50 \%$. However, it must be noted that eggs parasitized by T. remus remain at least four times longer in the field than unparasitized eggs because the duration of the egg stage is only two to three days during the warm summer months [16] whereas the development of T. remus at $25^{\circ} \mathrm{C}$ lasts 12 to 13 days [52]. Furthermore, parasitized eggs are dark, and thus more visible than unparasitized ones. Therefore, casual collections such as those carried out in Ghana (this study), Kenya and Tanzania [19] probably overestimate egg parasitism rates. In contrast, regular examinations of the same plants such as those conducted in Benin are more likely to provide more accurate parasitism rates.

\subsection{Prospects for Biological Control}

The presence of several parasitoids that can reach moderate or high parasitism rates under some conditions provides important information for the development of biological controls. Some parasitoids could be used for augmentative releases. The prospects for T. remus, which is already used in Latin America against S. frugiperda [53-55], have been elaborated in detail by [21]. This Asian species, deliberately introduced into the Americas, has been recently found in several African countries. Moreover, the finding of a Trichogramma sp. on S. frugiperda in Africa adds to the arsenal of natural enemies that could be exploited for control of this pest. Trichogramma spp. are commonly used in cereal crops for the augmentative biological control of S. frugiperda in the Americas [56,57]. Larval parasitoids are, in general, more difficult to use in open-field augmentative biological control than egg parasitoids because of the difficulty to produce them in high quantity for mass releases. However, there are exceptions, such as Habrobracon hebetor Say, which is used against $H$. albipunctella in millet fields in the Sahel region [58]. Some authors [22] discussed the potential of using C. luteum in augmentative biological control. The challenge of using a larval parasitoid of $S$. frugiperda in augmentative biological control will be to find alternate rearing hosts for mass production, since $S$. frugiperda is not suitable for the mass production of larval parasitoids due to the cannibalistic behaviour of the larvae [16].

The fact that parasitoids such as $C h$. bifoveolatus, C. luteum and T. remus can reach high rates of parasitism opens possibilities for conservation biological control. Cultural practices are known to enhance the parasitism of crop pests and various agroecological options may be used against S. frugiperda, such as replacing synthetic insecticides by botanicals or biopesticides, considering intercropping and other habitat management methods, or planting field margins [59]. However, the effect of these practices on parasitism of $S$. frugiperda remains to be studied.

Finally, the information on native parasitoids in West Africa gathered during this study may also help in selecting parasitoids for introduction from the Americas. For example, the abundance and 
high frequency of Ch. bifoveolatus in West Africa suggests that the introduction of Chelonus insularis Cresson, probably the most widespread and frequently cited parasitoid of $S$. frugiperda in its native range [25], may not be required, since it would directly compete with the local Ch. bifoveolatus. Their respective performance on $S$. frugiperda should be compared to assess whether $C$. insularis would show advantages compared to $C$. bivoveolatus. In contrast, the low population and incidence of $C$. icipe in the region and the absence of other microgasterine parasitoids may advocate for the introduction of Cotesia marginiventris (Cresson) one of the most important larval parasitoid of $S$. frugiperda on the American continent, known for a relatively good tolerance to pesticides in maize fields in the USA [28]. However, this parasitoid is recorded as being polyphagous [36] and potential non-target effects would need to be properly assessed before introduction into Africa. Parasitoids such as Eiphosoma spp. or Aleiodes spp., which are among the most specific parasitoids of $S$. frugiperda in the Americas $[25,60]$ do not yet have congeneric species attacking the pest in Africa and may thus be considered better options for introduction in Africa.

Supplementary Materials: The following are available online at http://www.mdpi.com/2075-4450/11/2/68/s1, Table S1: Description of the study sites in Ghana (GH) and Benin (BE).

Author Contributions: Data collection, L.K.A., G.G., P.B., S.A.M. and R.G.; morphological identifications, G.G. and M.K.; molecular and genetic analyses, A.B., G.C. and L.O.; writing-original draft preparation, L.K.A., G.G., I.R. and M.K.; writing-review and editing, P.B., V.A.C., R.D., A.B., G.C. and L.O.; Project administration, M.K., G.G., I.R., R.D. and L.K.A. All authors have read and agreed to the published version of the manuscript.

Funding: The research in Ghana was financially supported by the Department for International Development (DFID), UK, and the Directorate-General for International Cooperation (DGIS), Netherlands, through CABI's Action on Invasives programme. CABI is an international intergovernmental organisation, and we gratefully acknowledge the core financial support from our member countries (and lead agencies) including the United Kingdom (DFID), China (Chinese Ministry of Agriculture), Australia (Australian Centre for International Agricultural Research), Canada (Agriculture and Agri-Food Canada), Netherlands (DGIS), and Switzerland (Swiss Agency for Development and Cooperation). See http://www.cabi.org/about-cabi/who-we-work-with/key-donors/ for full details. Research activities carried out in the framework of this study at IITA-Benin were financially supported by the Federal Ministry for Economic Cooperation and Development (BMZ/GIZ).

Acknowledgments: We thank Andrew Polaszek, Nigel Wyatt and Gavin Broad from the Natural History Museum of London for their support in the identification of some parasitoids.

Conflicts of Interest: The authors declare that they have no conflict of interest.

\section{References}

1. Sparks, A.N. A review of the biology of the fall armyworm. Fla. Entomol. 1979, 62, 82-87. [CrossRef]

2. Montezano, D.G.; Specht, A.; Sosa-Gómez, D.R.; Roque-Specht, V.F.; Sousa-Silva, J.C.; Paula-Moraes, S.V.; Peterson, J.A.; Hunt, T.E. Host Plants of Spodoptera frugiperda (Lepidoptera: Noctuidae) in the Americas. Afr. Entomol. 2018, 26, 286-300. [CrossRef]

3. Day, R.; Abrahams, P.; Bateman, M.; Beale, T.; Clottey, V.; Cock, M.; Colmenarez, Y.; Corniani, N.; Early, R.; Godwin, J.; et al. Fall armyworm: Impacts and implications for Africa. Outlooks Pest Manag. 2017, 28, 196-201. [CrossRef]

4. Rwomushana, I.; Bateman, M.; Beale, T.; Beseh, P.; Cameron, K.; Chiluba, M.; Clottey, V.; Davis, T.; Day, R.; Early, R.; et al. Fall Armyworm: Impacts and Implications for Africa; CABI Evidence Note Update; CABI: Wallingford, UK, 2018.

5. CABI. Spodoptera Frugiperda. In Invasive Species Compendium; CAB International: Wallingford, UK, 2019; Available online: www.cabi.org/isc (accessed on 20 February 2019).

6. Goergen, G.; Kumar, P.L.; Sankung, S.B.; Togola, A.; Tamò, M. First report of outbreaks of the fall armyworm Spodoptera frugiperda (J.E. Smith) (Lepidoptera, Noctuidae), a new alien invasive pest in West and Central Africa. PLoS ONE 2016, 11, e0165632. [CrossRef] [PubMed]

7. Cock, M.J.W.; Beseh, P.K.; Buddie, A.G.; Cafá, G.; Crozier, J. Molecular methods to detect Spodoptera frugiperda in Ghana, and implications for monitoring the spread of invasive species in developing countries. Sci. Rep. 2017, 7, 4103. [CrossRef] [PubMed]

8. Prasanna, B.M.; Huesing, J.E.; Eddy, R.; Peschke, V.M. Fall Armyworm in Africa: A Guide for Integrated Pest Management, 1st ed.; CIMMYT: Mexico City, Mexico, 2018. 
9. Chimweta, M.; Nyakudya, I.W.; Jimu, L.; Mashingaidze, A.B. Fall armyworm [Spodoptera frugiperda (J.E. Smith)] damage in maize: Management options for flood-recession cropping smallholder farmers. Int. J. Pest Manag. 2019. [CrossRef]

10. Baudron, F.; Zaman-Allah, M.A.; Chaipa, I.; Chari, N.; Chinwada, P. Understanding the factors influencing fall armyworm (Spodoptera frugiperda J.E. Smith) damage in African smallholder maize fields and quantifying its impact on yield. A case study in Eastern Zimbabwe. Crop. Prot. 2019, 120, 141-150. [CrossRef]

11. Sisay, B.; Tefera, T.; Wakgari, M.; Ayalew, G.; Mendesil, E. The efficacy of selected synthetic insecticides and botanicals against fall armyworm, Spodoptera frugiperda, in Maize. Insects 2019, 10, 45. [CrossRef]

12. Kansiime, K.M.; Mugambi, I.; Rwomushana, I.; Nunda, W.; Lamontagne-Godwin, J.; Rware, H.; Phiri, N.A.; Chipabika, G.; Ndlovu, M.; Day, R. Farmer perception of fall armyworm (Spodoptera frugiderda J.E. Smith) and farm-level management practices in Zambia. Pest Manag. Sci. 2019. [CrossRef]

13. Kumela, T.; Simiyu, J.; Sisay, B.; Likhayo, P.; Mendesil, E.; Gohole, L.; Tefera, T. Farmers' knowledge, perceptions, and management practices of the new invasive pest, fall armyworm (Spodoptera frugiperda) in Ethiopia and Kenya. Int. J. Pest Manag. 2019, 65, 1-9. [CrossRef]

14. Yu, S.J. Insecticide resistance in the fall armyworm, Spodoptera frugiperda (J.E. Smith). Pestic. Biochem. Physiol. 1991, 39, 84-91. [CrossRef]

15. Togola, A.; Meseka, S.; Menkir, A.; Badu-Apraku, B.; Bouka, O.; Tamò, M.; Djouaka, R. Measurement of pesticide residues from chemical control of the invasive Spodoptera frugiperda (Lepidoptera: Noctuidae) in a maize experimental field in Mokwa, Nigeria. Int. J. Environ. Res. Public Health 2018, 15, 849. [CrossRef] [PubMed]

16. Bateman, M.L.; Day, R.K.; Luke, B.; Edgington, S.; Kuhlmann, U.; Cock, M.J.W. Assessment of potential biopesticide options for managing fall armyworm (Spodoptera frugiperda) in Africa. J. Appl. Entomol. 2018, 142, 805-819. [CrossRef]

17. Souza, M.; Giustolin, T.; Alvarenga, C.; Costa, J.; Aspiazú, I. Aqueous extract of pequi fruit to control Spodoptera frugiperda in corn. Arq. Inst. Biol. 2018, 85. [CrossRef]

18. Sisay, B.; Simiyu, J.; Malusi, P.; Likhayo, P.; Mendesil, E.; Elibariki, N.; Wakgari, M.; Ayalew, G.; Tefera, T. First report of the fall armyworm, Spodoptera frugiperda (Lepidoptera: Noctuidae), natural enemies from Africa. J. Appl. Entomol. 2018, 142, 800-804. [CrossRef]

19. Sisay, B.; Simiyu, J.; Mendesil, E.; Likhayo, P.; Ayalew, G.; Mohamed, S.; Subramanian, S.; Tefera, T. Fall armyworm, Spodoptera frugiperda infestations in East Africa: Assessment of damage and parasitism. Insects 2019, 10, 195. [CrossRef]

20. Tendeng, E.; Labou, B.; Diatte, M.; Djiba, S.; Diarra, K. The fall armyworm Spodoptera frugiperda (J.E. Smith), a new pest of maize in Africa: Biology and first native natural enemies detected. Int. J. Biol. Chem. Sci. 2019, 13, 1011-1026. [CrossRef]

21. Kenis, M.; du Plessis, H.; Van den Berg, J.; Ba, M.N.; Goergen, G.; Kwadjo, K.E.; Baoua, I.; Buddie, A.; Cafà, G.; Offord, L.; et al. Telenomus remus, a candidate parasitoid for the biological control of Spodoptera frugiperda in Africa, is already present on the continent. Insects 2019, 10, 92. [CrossRef]

22. Agboyi, L.K.; Mensah, S.A.; Clottey, V.A.; Beseh, P.; Glikpo, R.; Rwomushana, I.; Day, R.; Kenis, M. Evidence of Leaf Consumption Rate Decrease in Fall Armyworm, Spodoptera frugiperda, Larvae Parasitized by Coccygidium luteum. Insects 2019, 10, 410. [CrossRef]

23. Gross, H.R., Jr.; Pair, S.D. The fall army-worm: Status and expectations of biological control with parasitoids and predators. Fla. Entomol. 1986, 69, 502-515. [CrossRef]

24. Molina-Ochoa, J.; Hamm, J.J.; Lezama-Gutiérrez, R.; López-Edwards, M.; González-Ramírez, M.; Pescador-Rubio, A. A survey of fall armyworm (Lepidoptera: Noctuidae) parasitoids in the Mexican states of Michoacán, Colima, Jalisco, and Tamaulipas. Fla. Entomol. 2001, 84, 31-36. [CrossRef]

25. Molina-Ochoa, J.; Carpenter, J.E.; Heinrichs, E.A.; Foster, J.E. Parasitoids and parasites of Spodoptera frugiperda (Lepidoptera: Noctuidae) in the Americas and Caribbean Basin: An inventory. Fla. Entomol. 2003, 86, 254-289. [CrossRef]

26. Murúa, M.G.; Molina-Ochoa, J.; Fidalgo, P. Natural distribution of parasitoids of larvae of the fall armyworm, Spodoptera frugiperda, in Argentina. J. Insect Sci. 2009, 9, 20. [CrossRef]

27. Rios-Velasco, C.; Gallegos-Morales, G.; Cambero-Campos, J.; Cerna-Chávez, E.; Rincón-Castro, M.C.D.; Valenzuela-García, R. Natural enemies of the Fall Armyworm Spodoptera frugiperda (Lepidoptera: Noctuidae) in Coahuila, México. Fla. Entomol. 2011, 94, 723-726. [CrossRef] 
28. Meagher, R.L.; Nuessly, G.S.; Nagoshi, R.N.; Hay-Roe, M.N. Parasitoids attacking fall armyworm (Lepidoptera: Noctuidae) in sweet corn habitats. Biol. Control 2016, 95, 66-72. [CrossRef]

29. Van Driesche, R.G.; Bellows, T.S., Jr. Biological Control; Chapman and Hall: New York, NY, USA, 1996.

30. De Saeger, H. Exploration du Parc National Albert. Mission, G.F. de Witte (1933-1935); Fasc. 53, Cardiochilinae Et Sigalphinae (Hymenoptera Apocrita Fam. Braconidae); Institut des Parcs Nationaux du Congo Belge: Bruxelles, Belgium, 1948.

31. Goulet, H.; Huber, J.T. Hymenoptera of the World: An Identification Guide to Families; Centre for Land and Biological Resources Research Ottawa: Ottawa, ON, Canada, 1993.

32. Riedel, M. Contribution to the genus Metopius Panzer (Hymenoptera, Ichneumonidae, Metopiinae) from Africa South of Sahara. Linzer Biol. Beitr. 2016, 48, 1635-1676.

33. Fiaboe, K.K.; Fernández-Triana, J.; Nyamu, F.W.; Agbodzavu, K.M. Cotesia icipe sp. n., a new Microgastrinae wasp (Hymenoptera, Braconidae) of importance in the biological control of Lepidopteran pests in Africa. J. Hymenopt. Res. 2017, 61, 49. [CrossRef]

34. Ratnasingham, S.; Hebert, P.D.N. A DNA-based registry for all animal species: The Barcode Index Number (BIN) System. PLoS ONE 2013, 8, e66213. [CrossRef]

35. Clark, K.; Karsch-Mizrachi, I.; Lipman, D.J.; Ostell, J.; Sayers, E.W. GenBank. Nucleic Acids Res. 2016, 44, D67-D72. [CrossRef]

36. Sow, A.; Brevault, T.; Delvare, G.; Haran, J.; Benoit, L.; Cour d'Acier, A.; Galan, M.; Thiaw, C.; Soti, V.; Sembene, M. Sequencing to help identify crop pests and their natural enemies in agro-ecosystems: The case of the millet head miner Heliocheilus albipunctella (Lepidoptera: Noctuidae) in sub-Saharan Africa. Biol. Control. 2018, 121, 199-207. [CrossRef]

37. Yu, D.S.; Van Achterberg, K.; Horstmann, K. World Ichneumonoidea 2004. Taxonomy, Biology, Morphology and Distribution; CD/DVD. Taxapad: Vancouver, BC, Canada, 2005.

38. Madl, M.; van Achterberg, C. A catalogue of the Braconidae (Hymenoptera: Ichneumonoidea) of the Malagasy subregion. Linzer biol. Beitr. 2014, 46(1), 5-220.

39. Goergen, G. Unpublished Data; IITA: Cotonou, Benin, 2019.

40. Kittel, R.N. Eighty-nine replacement names for Braconidae and Ichneumonidae (Insecta: Hymenoptera: Ichneumonoidea). Jpn. J. Syst. Entomol. 2016, 22, 161-174.

41. Wiedemann, C.R.W. Achias Dipterorum Genus a Fabricio Conditum; Illustratum Novisque Auctum et Conventui Physicorum Germanorum Oblatum; Mohr: Kiliae, Kiel, Germany, 1830.

42. O'Hara, J.E.; Cerretti, P. Annoted catalogue of the Tachinidae (Insecta, Diptera) of the Afrotropical Region, with the description of seven new genera. ZooKeys 2016, 575, 1-344. [CrossRef] [PubMed]

43. Crosskey, R.W. The identity of Palexorista quadrizonula (Thomson), a tachinid parasite of lepidopterous pests in Africa. Bull. Entomol. Res. 1970, 59, 579-583. [CrossRef]

44. Merrett, P.J. Natural enemies of the african armyworm, Spodoptera exempta (Walker) (Lepidoptera: Noctuidae), in Tanzania. Bull. Entomol. Res. 1986, 76, 545-552. [CrossRef]

45. Silvie, P. Les parasitoïdes de Syllepte derogata (Fabricius, 1775) (Lepidoptera, Crambidae) au Togo. J. Afr. Zool. 1993, 107, 363-372.

46. Kumar, R.; Sampson, M. Review of stem borer research in Ghana. Int. J. Trop. Insect Sci. 1982, 3, 85-88. [CrossRef]

47. Obeng-Ofori, D.; Sackey, J. Field evaluation of non-synthetic insecticides for the management of insect pests of okra Abelmoschus esculentus (L.) Moench in Ghana. SINET Ethiop. J. Sci. 2003, 26, 145-150. [CrossRef]

48. Sarpong, G.A. The Legal Regime for the Control of Invasive Alien Species (IAS) in Ghana: Some Lessons in the Implementation of Treaty Norms. FAO Legal Papers. 2004. Available online: http://www.peacepalacelibrary. nl/ebooks/files/FAO_lpo40 (accessed on 10 June 2019).

49. Hordzi, W.H.K.; Botchey, M.A. Some parasitoids of lepidopterous stem borer pests on maize in Southern Ghana. Bull. Environ. Pharmacol. Life Sci. 2012, 1,77-83.

50. Agbodzavu, M.K.; Lagat, Z.O.; Gikungu, M.; Rwomushana, I.; Ekesi, S.; Fiaboe, K.K.M. Performance of the newly identified endoparasitoid Cotesia icipe Fernandez-Triana \& Fiaboe on Spodoptera littoralis (Boisduval). J. Appl. Entomol. 2018, 142, 646-653. [CrossRef]

51. Agbodzavu, M.K.; Lagat, Z.O.; Gikungu, M.; Rwomushana, I.; Ekesi, S.; Fiaboe, K.K.M. Acceptability and suitability of Spodoptera exigua (Hübner) for Cotesia icipe Fernandez-Triana \& Fiaboe on amaranth. J. Appl. Entomol. 2018, 142, 716-724. [CrossRef] 
52. Bueno, R.C.O.D.F.; Bueno, A.D.F.; Xavier, M.F.D.C.; Carvalho, M.M. Telenomus remus (Hymenoptera: Platygastridae) parasitism on eggs of Anticarsia gemmatalis (Lepidoptera: Eribidae) compared with its natural host Spodoptera frugiperda (Lepidoptera: Noctuidae). Ann. Entomol. Soc. Am. 2014, 107, 799-808. [CrossRef]

53. Cave, R.D. Biology, ecology and use in pest management of Telenomus remus. Biocontrol News Inf. 2000, 21, $21-26$.

54. Gutierrez-Martinez, A.; Tolon-Becerra, A.; Lastra-Bravo, X.B. Biological control of Spodoptera frugiperda eggs using Telenomus remus Nixon in maize-bean-squash polyculture. Am. J. Agric. Biol. Sci. 2012, 7, $285-292$. [CrossRef]

55. Pomari, A.F.; Bueno, A.D.F.; Bueno, R.C.O.D.F.; Junior, M.; de Oliveiras, A.; Fonseca, A.C.P.F. Releasing number of Telenomus remus (Nixon) (Hymenoptera: Platygastridae) against Spodoptera frugiperda Smith (Lepidoptera: Noctuidae) in corn, cotton and soybean. Ciência Rural 2013, 43, 377-382. [CrossRef]

56. Cruz, I.; Figueiredo, M.D.L.C.; Matoso, M.J. Controle Biológico de Spodoptera Frugiperda Utilizando o Parasitóide de ovos Trichogramma (No. 02964); EMBRAPA-CNPMS: Sete Lagoas, Brazil, 1999.

57. Bueno, R.C.O.D.F.; Bueno, A.D.F.; Parra, J.R.P.; Vieira, S.S.; Oliveira, L.J.D. Biological characteristics and parasitism capacity of Trichogramma pretiosum Riley (Hymenoptera, Trichogrammatidae) on eggs of Spodoptera frugiperda (JE Smith) (Lepidoptera, Noctuidae). Rev. Bras. Entomol. 2010, 54, 322-327. [CrossRef]

58. Ba, N.M.; Kabore, A.; Baoua, I.B.; Laouali, A.; Oumarou, M.; Dabire-Binso, C.; Sanon, A. Augmentative on-farm delivery methods for the parasitoid Habrobracon hebetor Say. (Hymenoptera: Braconidae) to control the millet head miner Heliocheilus albipunctella (de Joannis) (Lepidoptera: Noctuidae) in Burkina Faso and Niger. Biocontrol 2014, 59, 689-696. [CrossRef]

59. Harrison, R.D.; Thierfelder, C.; Baudron, F.; Chinwada, P.; Midega, C.; Schaffner, U.; van den Berg, J. Agro-ecological options for fall armyworm (Spodoptera frugiperda JE Smith) management: Providing low-cost, smallholder friendly solutions to an invasive pest. J. Environ. Manag. 2019, 243, 318-330. [CrossRef]

60. Cave, R.D. Parasitoides larvales y pupales de Spodoptera frugiperda (Smith) (Lepidoptera: Noctuidae) en Centro América con una clave para las especies encontradas en Honduras. Ceiba 1993, 34, 33-56.

(C) 2020 by the authors. Licensee MDPI, Basel, Switzerland. This article is an open access article distributed under the terms and conditions of the Creative Commons Attribution (CC BY) license (http://creativecommons.org/licenses/by/4.0/). 